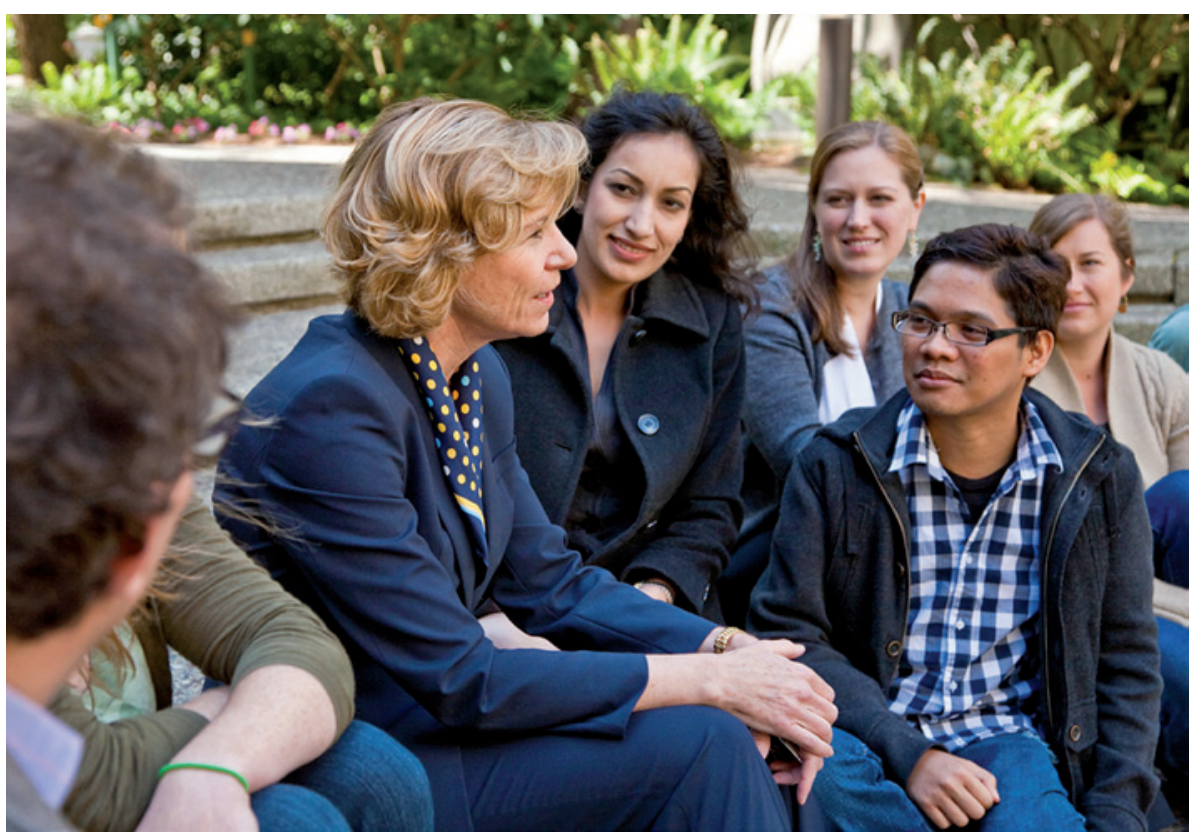

Chancellor Susan Desmond-Hellmann (centre) wants her campus to find its own way out of financial straits. FUNDING

\title{
Biomedical campus seeks freer rein
}

\section{University of California, San Francisco, wants more control over fund-raising as state budget crisis continues.}

\section{BY MONYA BAKER}

$\mathrm{I}$ might seem that the University of California, San Francisco (UCSF), has it all: dozens of scenic sites and a US $\$ 1.5$-billion state-of-the-art hospital under construction along the bay. A leading biomedical research centre, the university won $\$ 533$ million in funding from the US National Institutes of Health in 2011, more than any other institution except Johns Hopkins University in Baltimore, Maryland. But facing an uncertain health-care market, flat federal funding and a flagging state budget, UCSF is pursuing one thing it does not yet have: autonomy.

University chancellor Susan DesmondHellmann is scheduled to discuss relaxing ties with the greater University of California (UC) system at a meeting of the UC regents at UCSF's Mission Bay site on 18 July. The moves could help to alleviate UCSF's financial situation by giving the university the freedom to pursue new funding sources, but some observers are worried that the decentralization could herald a shake-up for the entire UC system.

"We're seeing the beginning of a situation that I find disappointing, but that doesn't surprise me," says Andrew Scull, a sociologist at UC, San Diego, who believes that the UC system is incapable of coping with the fiscal crisis. In 2009, Scull wrote a letter, signed by 22 other department heads in San Diego, arguing that UC funds should be concentrated at four flagship campuses (San Diego, Berkeley, Los Angeles and San Francisco) to insulate them from cutbacks.

Under current budget projections, UCSF will go into the red by 2015. Employee healthcare costs, retirement benefits and merit-based pay rises for faculty members are increasing, and UC's state funding for 2011-12 is down by $\$ 750$ million from $2010-11$.

Unlike the other nine UC campuses, UCSF cannot raise revenue by boosting tuition fees or increasing enrolment. It has no undergraduates, and graduate tuition fees generate only $1 \%$ of its $\$ 3$.9-billion annual budget. Half of UCSF's revenue comes from its clinical enterprise. But in the wake of the state budget crisis, UC has had to focus on fixing the undergraduate system at its other campuses, says Reg Kelly, director of the California Institute for Quantitative Biosciences, an effort to commercialize research run by UC's San Francisco, Berkeley and Santa Cruz campuses. "The unique

problems of UCSF in an evolving health-care market are not getting the regents' attention as much as they deserve."

In February, Desmond-Hellmann charged a 13-person working group of UCSF and UC administrators with exploring ways to help UCSF cope by changing its governance structure and financial relationship with the UC system. A report from that working group will be discussed at the meeting on 18 July.

UCSF does not want to secede or become a private institution. Rather, it wants increased operational flexibility and more opportunities to tap into local expertise. This could mean establishing its own board to help bring in funds through philanthropy and partnerships with drug companies. Working-group members and the chancellor declined to comment on the proposals before the meeting.

The research-intensive UCSF campus has long thought of itself as unique, says Christopher Scott, assistant vice-chancellor for research at UCSF from 2000 to 2002 and now a researcher in stem-cell policy at Stanford University in California. In his time, greater independence was discussed regularly, he says, in part because of the challenges that UCSF scientists faced in commercializing their research. UC as a whole puts fewer resources into technology licensing and imposes more constraints than private institutions, says Scott.

There are precedents for autonomy in the UC system: the Lawrence Berkeley and Lawrence Livermore national laboratories are supported by the US Department of Energy but managed by UC. And UCSF has a history of independence: in 1997, its medical centre and one of its hospitals merged with Stanford Health Services. But the merger lost money and caused tension among faculty members and employees, and the institutions separated in 2000.

If UCSF gains increased autonomy, Scull predicts, other campuses will want it too. In

\section{"We April, officials at}

"We'reseeing the beginning of a situation that I find disappointing, but that doesn't surprise me."

\section{some believe that a looser UC sys}

Some believe that a looser UC system is inevitable. As state funding is reduced, campuses want to secure their individual futures, says John Douglass, who studies higher education at Berkeley. He thinks that decentralization could allow the campuses to focus on regional economies, and create ties with local industries. But he would lament the loss of a UC sense of identity. UCSF's discussion with the regents next week is just another sign of hard times and would have been "unthinkable" 20 years ago, says Douglass. "How the institutions see themselves has changed so much with the decrease in funding." - 